\title{
Nitrogen management in the relationships between oat inflorescence components and productivity
}

\author{
Rubia D. Mantai ${ }^{1}$, José A. G. da Silva², Manuel O. Binelo³, Airam T. Z. R. Sausen, Dênis S. Rossi \& \\ Janiele S. Corso ${ }^{2}$ \\ ${ }^{1}$ Universidade Regional do Alto Uruguai e das Missões/Departamento de Ciências Exatas, Santo Ângelo, RS, Brasil. E-mail: rdmantai@san.uri.br \\ (Corresponding author) - ORCID: 0000-0003-3588-4849 \\ ${ }^{2}$ Universidade Regional do Noroeste do Estado do Rio Grande do Sul/Departamento de Estudos Agrários, Ijuí, RS, Brasil. E-mail: jagsfaem@yahoo.com.br - \\ ORCID: 0000-0002-9335-2421; janielecorso@outlook.com - ORCID: 0000-0001-7077-2602 \\ ${ }^{3}$ Universidade Regional do Noroeste do Estado do Rio Grande do Sul/Departamento de Ciências Exatas e Engenharias, Ijuí, RS, Brasil. E-mail: \\ manuel.binelo@unijui.edu.br - ORCID: 0000-0001-7639-7663; airam@unijui.edu.br - ORCID: 0000-0001-6499-4145; denisrossi0307@hotmail.com - \\ ORCID: 0000-0002-1445-704X
}

\begin{abstract}
Among oat inflorescence components there are different magnitudes of contribution to expression of grain and industrial productivity by nitrogen stimulation. Thus, it was proposed to size and interpret the contribution and dynamics of the relationships of oat inflorescence components with grain and industrial yield by $\mathrm{N}$-fertilizer stimulation, partitioning correlation values into direct and indirect effects by path diagnosis, strengthened by the joint analysis of different agricultural years. The study was carried out from 2011 to 2016, in the municipality of Augusto Pestana, RS, Brazil, in a randomized block design with four repetitions in a $4 \times 2$ factorial scheme for nitrogen doses $\left(0,30,60\right.$ and $\left.120 \mathrm{~kg} \mathrm{ha}^{-1}\right)$, using oat cultivars (Barbarasul and Brisasul) in soybean/oat and corn/oat systems. In the soybean/oat system, the mass and the number of panicle spikelets and the mass of panicle grains, contributed more to promoting changes by the increase of nitrogen. In the corn/oat system, the variables with the highest contribution are the mass and the number of panicle spikelets. The increase in panicle grain mass and in panicle harvest index increases grain yield, however, together with the number of panicle grains, they reduce industrial productivity, regardless of the cultivation system.
\end{abstract}

Key words: Avena sativa L., correlation and path, grain yield, industrial productivity, sustainability

\section{O manejo do nitrogênio nas relações entre componentes da inflorescência da aveia com a produtividade}

RESUMO: Existem entre os componentes da inflorescência da aveia diferentes magnitudes de contribuição de expressão da produtividade de grãos e industrial pelo estímulo do nitrogênio; deste modo, propôs-se dimensionar e interpretar a contribuição e a dinâmica de relações dos componentes da inflorescência da aveia com a produtividade de grãos e industrial pelo estímulo do fertilizante nitrogenado, particionando os valores de correlação em efeitos diretos e indiretos por diagnóstico de trilha, fortalecido pela análise conjunta de distintos anos agrícolas. O estudo foi conduzido de 2011 a 2016, no município de Augusto Pestana, RS, em delineamento experimental de blocos casualizados com quatro repetições em esquema fatorial $4 \times 2$ para doses de nitrogênio (0, 30, 60 e $120 \mathrm{~kg} \mathrm{ha}^{-1}$ ) e cultivares de aveia (Barbarasul e Brisasul) em sistema soja/aveia e milho/aveia. No sistema soja/aveia, a massa e o número de espiguetas da panícula e a massa de grãos da panícula, detém maior contribuição em promover alterações pelo incremento do nitrogênio. No sistema milho/ aveia, as variáveis com maior contribuição são, a massa e o número de espiguetas da panícula. O acréscimo da massa de grãos da panícula e do índice de colheita da panícula incrementam a produtividade de grãos, porém, juntamente com o número de grãos da panícula, reduzem a produtividade industrial, independente do sistema de cultivo.

Palavras-chave: Avena sativa L., correlação e trilha, produtividade de grãos, produtividade industrial, sustentabilidade 


\section{INTRODUCTION}

White oats are an important alternative for diversification and economic contribution to the productive system. Considered an extremely healthy cereal, it has been in high demand by the food industry due to its excellent nutritional value (Coelho et al., 2018; Silva et al., 2020). Grain yield is particularly of interest to farmers, and industrial productivity is desired for processing, as it involves the presence of wellformed grains with dimension greater than $2 \mathrm{~mm}$ and a greater volume of caryopsis in relation to husks (Alves \& Kist, 2010; Hawerroth et al., 2015).

The inadequate use of nitrogen fertilizer is a factor that limits and alter the expression of the direct and indirect components that makes up grain and industrial productivity (Marolli et al., 2017b; Song et al., 2019). Also, the weather conditions and the succession systems of high and reduced release of N-residual, alter the availability of nitrogen and the efficiency of use by the plant, implying changes with greater and lesser magnitude variables that explain productivity and quality (Arenhardt et al., 2015; Scremin et al., 2017).

Oat yield shows quantitative heritage with direct and indirect effects of several related components, such as panicle mass, number and mass of panicle grains, among others, with individual and/or combined modifications varying the final productivity (Cover et al., 2011; Hawerroth et al., 2015). In the most efficient nitrogen management, there is a need to know the dynamics of using oats in the elaboration of its components. This is so that, the association of grain and industrial productivity with inflorescence components, can optimize ways of using nutrients in the generation of more sustainable production systems.

The objective of this study was to size and interpret the contribution and relationship dynamics of oat inflorescence components with grain and industrial productivity by $\mathrm{N}$-fertilizer stimulation, partitioning the correlation values into direct and indirect effects by path analysis, strengthened by joint analysis of different agricultural years.

\section{Material ANd Methods}

This study was conducted in a field, in the agricultural years 2011 to 2016, in the municipality of Augusto Pestana, RS, Brazil, located geographically at $28^{\circ} 26^{\prime} 30^{\prime \prime} \mathrm{S}$ and $54^{\circ} 0^{\prime}$ $58^{\prime \prime} \mathrm{W}$ and altitude of $298 \mathrm{~m}$. The soil of the experimental area was classified as Oxisol and the climate of the region, according to the Köppen classification, is the Cfa type with hot summer without dry season (Kuinchtner \& Buriol, 2001; Santos et al., 2006). The experimental area is characterized by the occurrence of direct seeding twenty years ago, featuring a consolidated direct seeding system. In the summer period, the area is occupied by soybeans and corn, reflecting in the two crops previously used. In the implementation of the test, around 10 days before each sowing, a soil analysis was carried out, identifying, on average, the following chemical characteristics of the site (Tedesco et al., 1995): $\mathrm{pH}=6.3 ; \mathrm{P}$ $=34.1 \mathrm{mg} \mathrm{dm}^{-3} ; \mathrm{K}=231 \mathrm{mg} \mathrm{dm}^{-3} ; \mathrm{MO}=3.2 \% ; \mathrm{Al}=0 \mathrm{cmol}_{\mathrm{c}}$ $\mathrm{dm}^{-3} ; \mathrm{Ca}=6.6 \mathrm{cmol}_{\mathrm{c}} \mathrm{dm}^{-3}$ and $\mathrm{Mg}=2.9 \mathrm{cmol}_{\mathrm{c}} \mathrm{dm}^{-3}$.
Sowing was carried out between the first and the second weeks of June with a seeder-fertilizer. Each plot consisted of 5 rows measuring $5 \mathrm{~m}$ in length each, and spacing between rows of $0.20 \mathrm{~m}$, corresponding to an experimental unit of $5 \mathrm{~m}^{2}$. The population density used was 400 viable seeds per square meter. The seeds of the selected genotypes were submitted to germination and vigor tests in the laboratory, in order to correct the density of plants to compose the desired population. In the experiments, 60 and $50 \mathrm{~kg} \mathrm{ha}^{-1}$ of $\mathrm{P}_{2} \mathrm{O}_{5}$ and $\mathrm{K}_{2} \mathrm{O}$ were applied at sowing based on the levels of $\mathrm{P}$ and $\mathrm{K}$ in the soil for expected grain yield of $3 \mathrm{t} \mathrm{ha}^{-1}$, and $\mathrm{N}$ dose was $10 \mathrm{~kg} \mathrm{ha}^{-1}$ (except in the standard experimental unit). The remainder was covered in contemplation of the proposed doses of $\mathrm{N}$-fertilizer at the indicated phenological stage of the fourth expanded leaf, using urea as source. During the execution of the study, application of tebuconazole fungicide of the name FOLICUR ${ }^{\circledR}$ CE was carried out at a dose of $0.75 \mathrm{~L} \mathrm{ha}^{-1}$. In addition, weed control was performed with metsulfuron-methyl herbicide called ALLY ${ }^{\circledast}$ at a dose of $2.4 \mathrm{~g} \mathrm{ha}^{-1}$ and additional weeding whenever necessary.

The experimental design was a randomized block with four repetitions, following a $4 \times 2$ factorial scheme, with four doses of $\mathrm{N}$-fertilizer $\left(0,30,60\right.$ and $\left.120 \mathrm{~kg} \mathrm{ha}^{-1}\right)$, applied in the form of urea, and two oat cultivars (Barbarasul and Brisasul), respectively in soybean/oat and corn/oat succession systems; representing a system of high and reduced N-residual release, respectively. Harvesting of the experiments to estimate grain yield in each cultivation system occurred manually, by cutting the three central rows of each plot.

For the development of this study, the characters that make up the inflorescence of oats were used as explanatory variables: panicle length $(\mathrm{CP}, \mathrm{cm})$; number of panicle spikelet (NEP), per count; number of panicle grains (NGP), by count; panicle mass (MP, g), by weighing on a precision scale; mass of panicle grains (MGP, g); and panicle harvest index (ICP, $\mathrm{g} \mathrm{g}^{-1}$ ), determined by the ratio of the panicle grain mass to the panicle mass.

The main variables used were: grain productivity (PG, $\mathrm{kg} \mathrm{ha}^{-1}$ ), determined by the grain mass from the harvest of the three central rows of each plot; and industrial productivity (PI, $\mathrm{kg} \mathrm{ha}^{-1}$ ), obtained by the product of grain productivity with the percentage of caryopsis (\% Car) and the number of grains greater than $2 \mathrm{~mm}\left(\mathrm{NG}>{ }_{2 \mathrm{~mm}}\right)(\mathrm{PI}=\mathrm{PGx} \%$ Car $\left.\mathrm{NG}_{>2 \mathrm{~mm}}\right)$. The percentage of caryopsis was determined by the ratio between the weight of 50 grains without shell and the whole grain weight multiplied by 100 . The number of grains greater than $2 \mathrm{~mm}$ was determined by passing 100 grains through a $2 \mathrm{~mm}$ mesh sieve and those above this dimension were counted.

In the analysis of the relative contribution and correlation and path by nitrogen of the inflorescence components, for each dose of nitrogen and succession system, the data obtained by the cumulative effect of agricultural years and cultivar was used. This shows the strength of these relationships and their dynamics of action regardless of agricultural year and oat genotypes. The analyses of relative contribution and correlation and path of oat inflorescence components on the main variables, grain yield and industrial productivity by 
nitrogen use, were performed using the computer program Genes (Quantitative Genetics and Experimental Statistics, version 2015.5.0).

\section{Results AND Discussion}

The results contained in Table 1 present information on the temperature, and productivity of oat grains in different cultivation systems. It is noteworthy that the year 2011 was marked by well distributed rains during the oat cultivation cycle, with volumes similar to the historical average of the last 25 years. Rainfall precipitations were observed in the moments preceding the application of nitrogen, providing adequate soil moisture to solubilize urea as shown in Figure 1A. The maximum, minimum and average temperatures remained stable throughout the cultivation cycle.

In 2013, a uniform distribution of rainfall occurred between the months of cultivation of oats, however, it was below the historical average. At the time of $\mathrm{N}$-fertilizer application, there was adequate soil moisture due to rainfall in previous days, favoring nutrient utilization by the plant. In addition, temperatures were milder, reducing possible nitrogen losses through volatilization (Figure 1C). The minimum, maximum and average temperatures in 2013 were reduced, with stability throughout the cycle (Table 1). Yields above $3 \mathrm{t} \mathrm{ha}^{-1}$ of grain were observed both in the system with rapid release of $\mathrm{N}$-residual (soybean/oats) and in the system of slow release of $\mathrm{N}$-residual (corn/oats). These conditions, categorize the years 2011 and 2013 as favorable years (AF) to the productivity of oat grains.

In 2012 (Table 1), reduced precipitation was observed at the time of nitrogen application, combined with high temperatures, a fact that possibly may have led to the occurrence of nitrogen loss due to volatilization (Figure $1 \mathrm{~B})$. At the end of the cycle, the rains were more present and with greater accumulation, delaying grain harvest. In 2014, the first days of the cycle were marked by a volume of expressive rainfall above the historical average, along with high temperatures, a fact that can affect the efficiency of photosynthesis and the consequent formation of aerial parts (shoots) and root growth. At the time of nitrogen fertilization, the soil presented high humidity, with high air temperature, a condition that contributes to the volatilization of nitrogen, thereby decreasing the efficiency of nutrient absorption

Table 1. Mean values of temperature and rainfall in the months of cultivation and average yield of oat grains in succession systems, from 2011 to 2016

\begin{tabular}{|c|c|c|c|c|c|c|c|c|c|}
\hline \multirow{2}{*}{ Year } & \multirow{2}{*}{ Months } & \multicolumn{3}{|c|}{ Temperature $\left({ }^{\circ} \mathrm{C}\right)$} & \multicolumn{2}{|c|}{ Rainfall (mm) } & $P G_{X S}$ & \multirow[t]{2}{*}{$P G_{X M}$} & \multirow{2}{*}{ Class } \\
\hline & & Min & Max & Md & Average of 25 years * & Occurence & \multirow{7}{*}{$3686 a$} & & \\
\hline \multirow{6}{*}{2011} & June & 7.9 & 18.4 & 13.1 & 136 & 191 & & \multirow{6}{*}{$3122 \mathrm{a}$} & \multirow{6}{*}{$\mathrm{AF}$} \\
\hline & July & 8.3 & 19.2 & 13.7 & 134 & 201 & & & \\
\hline & August & 9.3 & 20.4 & 14.8 & 122 & 234 & & & \\
\hline & September & 95 & 23.7 & 16.6 & 165 & 46 & & & \\
\hline & October & 12.2 & 25.0 & 18.6 & 236 & 211 & & & \\
\hline & Total & - & - & - & 793 & 983 & & & \\
\hline \multirow{6}{*}{2012} & June & 8.8 & 22.0 & 15.4 & 136 & 57 & \multirow{6}{*}{$2378 c$} & \multirow{6}{*}{$1984 \mathrm{c}$} & \multirow{6}{*}{$A D$} \\
\hline & July & 6.4 & 19.7 & 13.0 & 134 & 180 & & & \\
\hline & Auqust & 12.9 & 23.4 & 18.1 & 122 & 61 & & & \\
\hline & September & 12.0 & 23.0 & 17.5 & 165 & 195 & & & \\
\hline & October & 15.0 & 25.5 & 20.2 & 236 & 287 & & & \\
\hline & Total & - & - & - & 793 & 780 & & & \\
\hline \multirow{6}{*}{2013} & June & 8.9 & 20.0 & 14.5 & 136 & 74 & \multirow{6}{*}{$3731 \mathrm{a}$} & \multirow{6}{*}{3269 a } & \multirow{6}{*}{$\mathrm{AF}$} \\
\hline & Julv & 70 & 20.6 & 13.8 & 134 & 103 & & & \\
\hline & August & 6.6 & 19.8 & 13.2 & 122 & 169 & & & \\
\hline & September & 96 & 21.0 & 15.3 & 165 & 123 & & & \\
\hline & October & 13.2 & 27.1 & 20.2 & 236 & 144 & & & \\
\hline & Total & - & - & - & 793 & 613 & & & \\
\hline \multirow{6}{*}{2014} & June & 9.2 & 20.7 & 16.1 & 136 & 412 & \multirow{6}{*}{$2181 d$} & \multirow{6}{*}{$1765 d$} & \multirow{6}{*}{$A D$} \\
\hline & July & 9.7 & 21.8 & 15.7 & 134 & 144 & & & \\
\hline & August & 8.8 & 23.7 & 16.2 & 122 & 78 & & & \\
\hline & September & 13.3 & 23.5 & 18.4 & 165 & 275 & & & \\
\hline & October & 16.0 & 27.7 & 21.8 & 236 & 231 & & & \\
\hline & Total & - & - & - & 793 & 1140 & & & \\
\hline \multirow{6}{*}{2015} & June & 9.7 & 21.1 & 15.4 & 136 & 228 & \multirow{6}{*}{$3451 \mathrm{~b}$} & & \\
\hline & July & 10.2 & 18.7 & 14.4 & 134 & 212 & & & \\
\hline & August & 13.4 & 24.6 & 19.0 & 122 & 87 & & & \\
\hline & September & 12.4 & 19.6 & 16.0 & 165 & 127 & & $2132 \mathrm{~b}$ & Al \\
\hline & October & 16.1 & 24.8 & 20.4 & 236 & 162 & & & \\
\hline & Total & - & - & - & 793 & 816 & & & \\
\hline & June & 4.7 & 19.3 & 12.0 & 136 & 12 & & & \\
\hline & July & 8.2 & 21.2 & 14.7 & 134 & 81 & & & \\
\hline & August & 9.4 & 22.5 & 15.9 & 122 & 169 & & & \\
\hline 2016 & September & 8.4 & 23.8 & 16.1 & 165 & 56 & $3335 \mathrm{~b}$ & $2782 b$ & Al \\
\hline & October & 13.2 & 26.8 & 20.0 & 236 & 326 & & & \\
\hline & Total & - & - & - & 793 & 644 & & & \\
\hline
\end{tabular}

Min - Minimum; Max - Maximum; Md -Average; PGXS- Average grain yield of the soy/oat system; PGXM-Average grain yield of the corn/oat system; ${ }^{*}$ Average rainfall obtained from May to October from 1989 to 2016; Averages followed by the same letter in the column do not differ at p $\leq 0.05$ by the Scott \& Knott test; AI - Intermediate year; AF - Favorable year; AD - Unfavorable year 


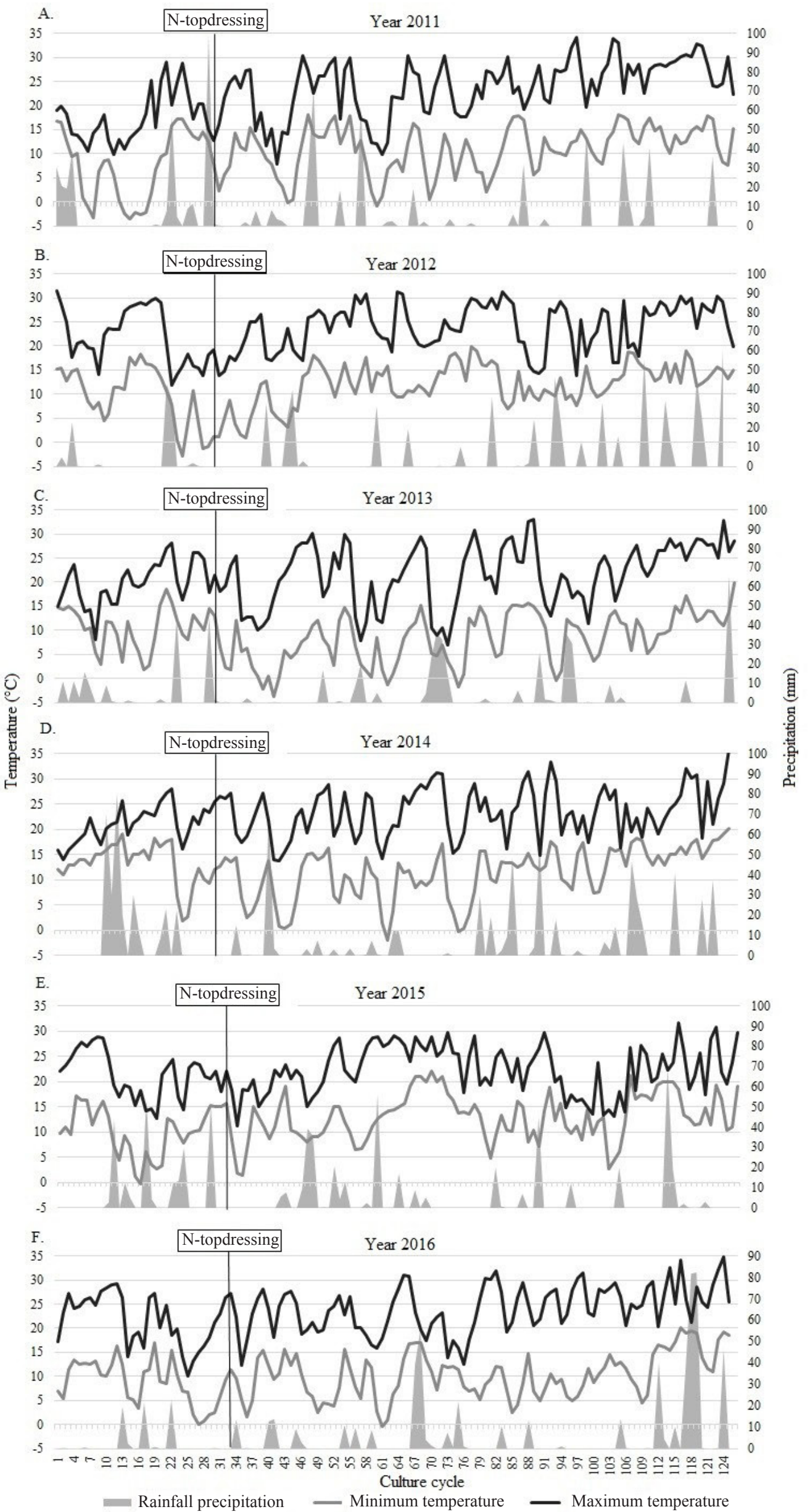

Figure 1. Meteorological data of temperature and precipitation in the cultivation years of 2011 (A), 2012 (B), 2013 (C), 2014 (D), 2015 (E) and 2016 (F). N-topdressing: nitrogen application time 
(Figure 1D). This year, there was also frequent rainfall at the end of the oat cycle, when minimal precipitation was desired in cereals. In the years 2012 and 2014, grain yield was below the desired expectation of $3 \mathrm{t} \mathrm{ha}^{-1}$, mainly in the system of slow decomposition of residual $\mathrm{N}$ (corn/oats). These conditions justify the classification of the years 2012 and 2014 as unfavorable years (AD) to the productivity of oat grains.

In 2015 (Table 1), the accumulated rainfall was close to the observed average of 25 years. The high humidity of the soil favoured the application of nitrogen. However, a dry period observed after fertilization may have affected the crop (Figure 1E). Indeed, the highlights were the high temperatures that occurred during anthesis, when reproductive system development is particularly sensitive to water stress and high temperatures. The year 2016 was marked by low rainfall, mainly in the grain filling period, however, heavy rains occurred in the final phase of the cycle, a time when grain yield has already been defined, but with an influence on grain quality (Figura 1F). In these agricultural year conditions, the influence of the low $\mathrm{C} / \mathrm{N}$ ratio (soybean/oat) system is identified, which possibly, due to the greater contribution of $\mathrm{N}$-residual, caused the grain yield to exceed the expectation of $3 \mathrm{t} \mathrm{ha}^{-1}$, a fact that did not occur in high $\mathrm{C} / \mathrm{N}$ ratio (corn/ oat). These facts were observed for the years 2015 and 2016, characterized as intermediate years (AI) in the yield of oat grains.

Although the climate of the South region is conducive to the development of white oats with quality and high productivity, the occurrence of diseases and weather conditions act as limiting factors to the expression of the productive potential of the crop (Silva et al., 2016). Meteorological factors, such as temperature and rainfall, alter the productivity and quality of oat grains, being considerably maximized as the conditions of the growing environment improve (Klink et al., 2014; Coelho et al., 2018). A favorable environment for the development of oats with high productivity and grain quality, requires an adequate distribution of rainfall during the cultivation cycle and in small quantities, with low temperatures from germination to the grain filling phase and high daytime temperatures during the maturation period (Souza et al., 2013; Marolli et al., 2017b). Therefore, up-to-date knowledge of meteorological information with management practices is essential for sustainable agriculture (Prando et al., 2013; Aseeva \& Melnichuk, 2018).

Table 2, shows the mean values and relative contribution for the effect of nitrogen in the soybean/oat system. The indicators of oat inflorescence that showed the most changes included the panicle mass, the number of spikelets and the panicle grain mass. These variables show, through mean values, a growth trend due to the increase in fertilization. Therefore, they show themselves as having the greatest capacity to favor grain productivity by using the nutrient. In the analysis of the corn/oat system, the number of spikelets and panicle mass showed great alteration by the use of nitrogen, increasing the mean values of these variables. The number of panicle grains and the panicle harvest index were also important, different from that in the soybean/oat system. This condition shows that straw with high and reduced release of N-residual also
Table 2. Mean values and relative nitrogen contribution on oat inflorescence indicators in different cultivation systems

\begin{tabular}{|c|c|c|c|c|c|c|}
\hline \multirow{2}{*}{ Variables } & \multicolumn{4}{|c|}{ Dose N (kg ha-1) } & \multicolumn{2}{|c|}{ Relative contribution } \\
\hline & 0 & 30 & 60 & 120 & S.j & S.j (\%) \\
\hline & \multicolumn{6}{|c|}{$\begin{array}{c}(2011+2012+2013+2014+2015+2016) \\
\text { Soybean/oat system }\end{array}$} \\
\hline$P G$ & 2437 & 3091 & 3531 & 3449 & - & - \\
\hline $\mathrm{PI}$ & 989 & 1297 & 1492 & 1424 & - & - \\
\hline $\mathrm{CP}$ & 19 & 19 & 19 & 19 & 0.06 & 0.58 \\
\hline NEP & 41 & 41 & 44 & 47 & 2.77 & 28.12 \\
\hline NGP & 76 & 76 & 80 & 84 & 0.87 & 8.88 \\
\hline MP & 2.57 & 2.59 & 2.65 & 2.73 & 3.29 & 33.39 \\
\hline MGP & 2.08 & 2.10 & 2.17 & 2.22 & 2.83 & 28.73 \\
\hline \multirow[t]{2}{*}{ ICP } & 0.81 & 0.81 & 0.81 & 0.81 & 0.30 & 0.30 \\
\hline & \multicolumn{6}{|c|}{ Corn/oat system } \\
\hline$P G$ & 1628 & 2462 & 3017 & 3328 & - & - \\
\hline $\mathrm{Pl}$ & 644 & 953 & 1255 & 1344 & - & - \\
\hline $\mathrm{CP}$ & 18 & 19 & 19 & 20 & 0.69 & 4.02 \\
\hline NEP & 34 & 40 & 46 & 47 & 5.71 & 33.05 \\
\hline NGP & 59 & 71 & 81 & 84 & 1.88 & 10.90 \\
\hline MP & 1.98 & 2.39 & 2.63 & 2.71 & 6.10 & 35.33 \\
\hline MGP & 1.54 & 1.86 & 2.14 & 2.19 & 1.12 & 6.46 \\
\hline ICP & 0.78 & 0.79 & 0.81 & 0.81 & 1.77 & 10.24 \\
\hline
\end{tabular}

PG - Grain productivity $\left(\mathrm{kg} \mathrm{ha}^{-1}\right)$; PI -Industrial productivity $\left(\mathrm{kg} \mathrm{ha}^{-1}\right)$; CP - Panicle length $(\mathrm{cm})$; NEP -Number of panicle spikelet; NGP -Number of panicle grains; MP Panicle mass (g); MGP - Panicle grain mass (g); ICP - Panicle harvest index; S.j Relative contribution of characteristics to genetic diversity according to Singh (1981)

interferes with panicle components, thus influencing grain yield.

Table 3 shows the direct and indirect relationships and effects of the variables linked to oat inflorescence with grain and industrial productivity, under nitrogen doses, in the soybean/ oat system. The observed relationships involved the variability of agricultural years, considering favorable, intermediate and unfavorable years for oat grain productivity. It is noteworthy that the correlation of grain yield was significant only for panicle mass, panicle grain mass and panicle harvest index. Among these, panicle mass was significant only at doses of 30 and $60 \mathrm{~kg} \mathrm{ha}^{-1}$ of nitrogen, showing a large negative indirect effect via panicle length and positive via panicle grain mass. Therefore, the increase in productivity is influenced by the expression of panicle grain mass without promoting an increase in panicle length under these conditions.

The correlation between grain yield and panicle grain mass was significant in all nitrogen doses, indicating that both the number of grains and the panicle length show a negative indirect effect (Table 3 ). On the other hand, the relationship between grain productivity and panicle grain mass shows a positive indirect relationship, via panicle mass, indicating that the attributes that provide grain filling can favor productivity. This fact is confirmed by analysis of the relationship between grain mass and panicle mass in determining the panicle harvest index. The panicle harvest index was directly correlated with productivity in a positive way in all nitrogen doses, a contribution that occurs indirectly by the panicle grain mass. Under these conditions, it was observed that the variables panicle grain mass and panicle harvest index favor grain yield increase. However, with the negative indirect influence of panicle length, the increase of this variable reduces the panicle grain mass and panicle harvesting index, thus reflecting on the grain yield. 
Table 3. Correlation and path of grain and industrial productivity on indicators of oat inflorescence in the use of nitrogen in the soybean/oat system

\begin{tabular}{|c|c|c|c|c|c|c|c|c|c|c|}
\hline \multirow{4}{*}{ VAR } & \multirow{2}{*}{ EF } & \multicolumn{4}{|c|}{ Doses of $N\left(\mathrm{~kg} \mathrm{ha}^{-1}\right)$} & \multirow{2}{*}{ EF } & \multicolumn{4}{|c|}{ Doses of $\mathrm{N}\left(\mathrm{kg} \mathrm{ha}^{-1}\right)$} \\
\hline & & 0 & 30 & \multicolumn{2}{|c|}{$60 \quad 120$} & & 0 & 30 & 60 & 120 \\
\hline & \multicolumn{10}{|c|}{$(2011+2012+2013+2014+2015+2016)$} \\
\hline & \multicolumn{5}{|c|}{ Contribution for grain productivity } & \multicolumn{5}{|c|}{ Contribution for industrial productivity } \\
\hline \multirow{7}{*}{$\mathrm{CP}$} & $r(P G X C P)$ & -0.17 & -0.06 & -0.15 & -0.08 & $r(P \mid x C P)$ & $-0.47^{*}$ & -0.23 & -0.24 & $-0.40^{*}$ \\
\hline & $\mathrm{D}: \mathrm{PG}$ & -0.98 & -0.99 & -0.89 & -0.73 & D:PI & -0.20 & 0.35 & 0.13 & 0.10 \\
\hline & ID: NEP & 0.37 & -0.01 & -0.29 & 0.25 & ID: NEP & 0.19 & -0.02 & -0.48 & 0.55 \\
\hline & ID:NGP & -0.54 & -0.52 & -0.32 & -0.77 & ID:NGP & -0.95 & -0.80 & -0.75 & -0.99 \\
\hline & ID: MP & 0.38 & 0.67 & 0.70 & 0.43 & ID: MP & 0.34 & 0.08 & 0.49 & -0.16 \\
\hline & ID:MGP & 0.60 & 0.81 & 0.63 & 0.59 & ID:MGP & 0.26 & 0.24 & 0.40 & 0.30 \\
\hline & ID: ICP & 0.00 & -0.02 & 0.01 & 0.13 & ID: ICP & -0.11 & -0.08 & -0.03 & -0.20 \\
\hline \multirow{7}{*}{ NEP } & $r$ (PGxNEP) & 0.04 & 0.21 & 0.24 & 0.25 & r (PIXNEP) & $-0.41^{*}$ & -0.34 & -0.35 & $-0.51^{*}$ \\
\hline & $D: P G$ & 0.43 & 0.00 & -0.31 & 0.29 & $\mathrm{D}: \mathrm{PI}$ & 0.20 & -0.03 & -0.54 & 0.48 \\
\hline & ID: CP & -0.99 & -0.91 & -0.78 & -0.63 & ID: CP & -0.19 & 0.31 & 0.08 & 0.03 \\
\hline & ID:NGP & -0.66 & -0.54 & -0.33 & -0.90 & ID:NGP & -0.99 & -0.86 & -0.86 & -0.99 \\
\hline & ID: MP & 0.49 & 0.71 & 0.81 & 0.59 & ID: MP & 0.40 & 0.08 & 0.56 & -0.12 \\
\hline & ID:MGP & 0.76 & 0.97 & 0.82 & 0.76 & ID:MGP & 0.29 & 0.27 & 0.53 & 0.21 \\
\hline & ID: ICP & 0.01 & -0.02 & 0.03 & 0.14 & ID: ICP & -0.12 & -0.11 & -0.12 & -0.12 \\
\hline \multirow{7}{*}{ NGP } & $r$ (PGXNGP) & 0.08 & 0.20 & 0.25 & 0.22 & $r(P \mid x N G P)$ & $-0.43^{\star}$ & $-0.39 *$ & $-0.35^{\star}$ & $-0.58^{*}$ \\
\hline & $D: P G$ & -0.68 & -0.54 & -0.33 & -0.90 & $\mathrm{D}: \mathrm{PI}$ & -0.99 & -0.87 & -0.87 & -0.99 \\
\hline & ID: CP & -0.91 & -0.93 & -0.77 & -0.61 & ID: CP & -0.22 & 0.32 & 0.08 & 0.00 \\
\hline & ID:NEP & 0.42 & 0.00 & -0.31 & 0.29 & ID:NEP & 0.10 & -0.03 & -0.54 & 0.56 \\
\hline & ID: MP & 0.53 & 0.72 & 0.81 & 0.59 & ID: MP & 0.43 & 0.05 & 0.57 & -0.19 \\
\hline & ID:MGP & 0.76 & 0.97 & 0.82 & 0.76 & ID:MGP & 0.25 & 0.28 & 0.52 & 0.21 \\
\hline & ID: ICP & 0.04 & -0.02 & 0.03 & 0.09 & ID: ICP & 0.00 & -0.14 & -0.11 & -0.17 \\
\hline \multirow{7}{*}{ MP } & $r(P G x M P)$ & 0.23 & $0.35^{\star}$ & $0.35^{*}$ & 0.27 & $r(\mathrm{PIXMP})$ & -0.26 & -0.21 & -0.15 & $-0.45^{\star}$ \\
\hline & $D: P G$ & 0.57 & 0.78 & 0.86 & 0.61 & D:PI & 0.45 & 0.09 & 0.59 & -0.13 \\
\hline & ID: CP & -0.83 & -0.87 & -0.73 & -0.55 & ID: CP & -0.20 & 0.30 & 0.13 & 0.00 \\
\hline & ID:NEP & 0.39 & 0.00 & -0.29 & 0.28 & ID:NEP & 0.18 & -0.03 & -0.51 & 0.65 \\
\hline & ID: NGP & -0.66 & -0.50 & -0.32 & -0.87 & ID: NGP & -0.98 & -0.81 & -0.83 & -0.99 \\
\hline & ID:MGP & 0.77 & 0.91 & 0.78 & 0.72 & ID:MGP & 0.25 & 0.26 & 0.50 & 0.20 \\
\hline & ID: ICP & -0.01 & 0.03 & 0.05 & 0.08 & ID: ICP & 0.04 & -0.02 & -0.03 & -0.18 \\
\hline \multirow{7}{*}{ MGP } & $r$ (PGXMGP) & $0.45^{*}$ & $0.43^{*}$ & $0.53^{*}$ & $0.42^{*}$ & $r(P \mid x M G P)$ & $-0.43^{*}$ & $-0.40^{*}$ & $-0.32^{\star}$ & $-0.61^{*}$ \\
\hline & $D: P G$ & 0.93 & 0.99 & 0.88 & 0.79 & $\mathrm{D}: \mathrm{PI}$ & 0.36 & 0.30 & 0.56 & 0.22 \\
\hline & ID: CP & -0.81 & -0.78 & -0.60 & -0.55 & ID: CP & -0.15 & 0.27 & 0.12 & 0.03 \\
\hline & ID:NEP & 0.40 & 0.04 & -0.28 & 0.28 & ID:NEP & 0.13 & -0.01 & -0.51 & 0.55 \\
\hline & ID: NGP & -0.56 & -0.49 & -0.29 & -0.88 & ID: NGP & -0.93 & -0.82 & -0.80 & -0.99 \\
\hline & ID: MP & 0.45 & 0.69 & 0.75 & 0.56 & ID: MP & 0.37 & 0.08 & 0.52 & -0.11 \\
\hline & ID: ICP & 0.04 & -0.02 & 0.07 & 0.22 & ID: ICP & -0.27 & -0.22 & -0.21 & -0.31 \\
\hline \multirow{9}{*}{ ICP } & r (PGXICP) & $0.37^{*}$ & $0.38^{*}$ & $0.43^{*}$ & 0.41 * & r (PIXICP) & $-0.41^{*}$ & $-0.47^{\star}$ & $-0.45^{\star}$ & $-0.60^{*}$ \\
\hline & $D: P G$ & 0.08 & 0.02 & 0.13 & 0.37 & $\mathrm{D}: \mathrm{PI}$ & -0.54 & -0.39 & -0.41 & -0.60 \\
\hline & ID: CP & -0.19 & -0.45 & -0.07 & -0.25 & ID: CP & -0.04 & 0.07 & 0.00 & 0.10 \\
\hline & ID:NEP & 0.03 & 0.10 & -0.09 & 0.10 & ID:NEP & 0.01 & -0.02 & -0.16 & 0.34 \\
\hline & ID: NGP & 0.03 & -0.42 & -0.09 & -0.31 & ID: NGP & 0.03 & -0.31 & -0.22 & -0.69 \\
\hline & ID: MP & -0.04 & 0.15 & 0.08 & 0.10 & ID: MP & -0.04 & 0.01 & 0.04 & -0.02 \\
\hline & ID: MGP & 0.46 & 0.98 & 0.47 & 0.40 & ID: MGP & 0.17 & 0.17 & 0.30 & 0.27 \\
\hline & k & $3.7 e^{-2}$ & $3.7 \mathrm{e}^{-2}$ & $5.1 \mathrm{e}^{-2}$ & $3.9 \mathrm{e}^{-2}$ & Valor k & $1.6 \mathrm{e}^{-2}$ & $1.1 e^{-2}$ & $3.3 e^{-2}$ & $1.4 e^{-2}$ \\
\hline & $\mathrm{R}^{2}$ & 0.72 & 0.67 & 0.79 & 0.58 & $\mathrm{R}^{2}$ & 0.64 & 0.77 & 0.51 & 0.61 \\
\hline
\end{tabular}

VAR -Variable; EF -Effect; PG - Grain productivity (kg ha $\left.{ }^{-1}\right)$; CP - Panicle length (cm); NEP -Number of panicle spikelet; NGP -Number of panicle grains; MP - Panicle mass (g); MGP - Panicle grain mass (g); ICP - Panicle harvest index; PI -Industrial productivity $\left(\mathrm{kg} \mathrm{ha}^{-1}\right)$; $\mathrm{r}$ - Coefficient of correlation; D -Direct contribution; ID - Indirect contribution; $\mathrm{R}^{2}$ - Coefficient of determination; $\mathrm{k}$ - Linearization coefficient; ${ }^{*}$ - Significant at $\mathrm{p} \leq 0.05$ by $\mathrm{F}$ test

In Table 3, in the soybean/oat system, the correlation between industrial productivity and oat inflorescence indicators was effective only for the number and mass of panicle grains and the panicle harvest index. Industrial productivity with the number of grains per panicle shows a negative direct correlation, indicating that the increase in the number of panicle grains promotes a reduction in industrial productivity. It is noteworthy that the correlation of industrial productivity with panicle grain mass is negative in all conditions of nitrogen use. This relationship brings a strong negative indirect contribution via the number of grains per panicle. This confirms that the increase in the number of grains, regardless of the condition of nitrogen use, promotes a reduction in industrial productivity. Industrial productivity shows a significant negative correlation with the panicle harvest index, in all conditions of nitrogen use, mainly via direct effect with industrial productivity and indirectly via the number of panicle grains. In these conditions, it was observed that industrial productivity can be high with reduction of the variables: panicle grain mass and number of panicle grains.

In Table 4, from the correlation and path of grain and industrial productivity on indicators of oat inflorescence in the use of nitrogen in a corn/oat system, the correlation between grain productivity and panicle length was significant and negative in all nitrogen use conditions. Even with a strong direct negative effect on grain yield. In this way, increasing panicle length decreases grain yield. In the supply of nitrogen up to the dose of $60 \mathrm{~kg} \mathrm{ha}^{-1}$, positive correlations were 
Table 4. Correlation and path of grain and industrial yield on indicators of oat inflorescence in the use of nitrogen in the corn/ oat system

\begin{tabular}{|c|c|c|c|c|c|c|c|c|c|c|}
\hline \multirow{4}{*}{ VAR } & EE & \multicolumn{4}{|c|}{ Doses of $N\left(\mathrm{~kg} \mathrm{ha}^{-1}\right)$} & \multirow{2}{*}{ EF } & \multicolumn{4}{|c|}{ Doses of $N\left(\mathrm{~kg} \mathrm{ha}^{-1}\right)$} \\
\hline & EF & 0 & 30 & 60 & 120 & & $\mathbf{0}$ & 30 & 60 & 120 \\
\hline & \multicolumn{10}{|c|}{$(2011+2012+2013+2014+2015+2016)$} \\
\hline & \multicolumn{5}{|c|}{ Contribution for grain productivity } & \multicolumn{5}{|c|}{ Contribution for industrial productivity } \\
\hline \multirow{7}{*}{$\mathrm{CP}$} & $r(P G X C P)$ & $-0.46^{*}$ & $-0.39 *$ & $-0.44^{*}$ & $-0.37^{\star}$ & $r(P \mid x C P)$ & -0.36 & -0.15 & -0.23 & $-0.52^{*}$ \\
\hline & $\mathrm{D}: \mathrm{PG}$ & -0.99 & -0.98 & -0.99 & -0.99 & $\mathrm{D}: \mathrm{PI}$ & -0.26 & 0.36 & 0.04 & 0.18 \\
\hline & ID: NEP & -0.08 & -0.10 & 0.44 & 0.52 & ID: NEP & -0.24 & -0.10 & 0.37 & 0.66 \\
\hline & ID:NGP & -0.11 & -0.46 & -0.17 & -0.17 & ID:NGP & -0.52 & -0.99 & -0.11 & -0.43 \\
\hline & ID: MP & 0.35 & 0.61 & -0.10 & -0.14 & ID: MP & 0.39 & 0.30 & -0.28 & -0.56 \\
\hline & ID:MGP & 0.37 & 0.80 & 0.38 & 0.40 & ID:MGP & -0.06 & 0.33 & -0.19 & -0.31 \\
\hline & ID: ICP & 0.00 & 0.01 & 0.00 & 0.01 & ID: ICP & 0.35 & -0.08 & -0.05 & -0.07 \\
\hline \multirow{7}{*}{ NEP } & $r$ (PGXNEP) & 0.01 & 0.06 & 0.03 & -0.01 & r (PIxNEP) & -0.20 & -0.23 & -0.29 & $-0.53^{*}$ \\
\hline & $D: P G$ & -0.09 & -0.11 & 0.59 & 0.71 & $\mathrm{D}: \mathrm{PI}$ & -0.30 & -0.13 & 0.47 & 0.71 \\
\hline & ID: CP & -0.86 & -0.98 & -0.82 & -1.21 & ID: CP & -0.21 & 0.34 & 0.03 & 0.17 \\
\hline & ID:NGP & -0.11 & -0.50 & -0.21 & -0.07 & ID:NGP & -0.61 & -0.99 & -0.14 & -0.45 \\
\hline & ID: MP & 0.53 & 0.73 & -0.11 & -0.04 & ID: MP & 0.54 & 0.31 & -0.40 & -0.62 \\
\hline & ID:MGP & 0.54 & 0.91 & 0.54 & 0.57 & ID:MGP & -0.06 & 0.40 & -0.26 & -0.35 \\
\hline & ID: ICP & 0.01 & 0.01 & 0.01 & 0.00 & ID: ICP & 0.46 & -0.16 & -0.01 & -0.02 \\
\hline \multirow{7}{*}{ NGP } & $r$ (PGXNGP) & 0.01 & 0.04 & 0.01 & -0.05 & $r(\mathrm{PIxNGP})$ & -0.26 & $-0.32^{\star}$ & -0.36 * & $-0.61^{*}$ \\
\hline & $D: P G$ & -0.12 & -0.51 & -0.21 & -0.07 & $\mathrm{D}: \mathrm{PI}$ & -0.62 & -0.85 & -0.14 & -0.46 \\
\hline & ID: CP & -0.89 & -0.98 & -0.83 & -0.99 & ID: CP & -0.22 & 0.30 & 0.03 & 0.17 \\
\hline & ID:NEP & -0.09 & -0.11 & 0.58 & 0.61 & ID:NEP & -0.30 & 0.14 & 0.46 & 0.71 \\
\hline & ID: MP & 0.52 & 0.72 & -0.20 & -0.08 & ID: MP & 0.53 & -0.16 & -0.40 & -0.62 \\
\hline & ID:MGP & 0.55 & 0.93 & 0.52 & 0.47 & ID:MGP & -0.10 & 0.37 & -0.27 & -0.35 \\
\hline & ID: ICP & 0.03 & 0.01 & -0.03 & 0.01 & ID: ICP & 0.47 & -0.12 & -0.03 & -0.04 \\
\hline \multirow{7}{*}{ MP } & $r(P G x M P)$ & 0.13 & 0.19 & 0.04 & -0.02 & r (PIXMP) & -0.08 & -0.07 & -0.31 & $-0.52^{\star}$ \\
\hline & $D: P G$ & 0.54 & 0.77 & 0.58 & -0.04 & D:PI & 0.55 & 0.33 & -0.41 & -0.64 \\
\hline & ID: CP & -0.76 & -0.87 & -0.72 & -0.99 & ID: CP & -0.19 & 0.29 & 0.02 & 0.16 \\
\hline & ID:NEP & -0.09 & -0.11 & 0.55 & 0.59 & ID:NEP & -0.29 & -0.12 & 0.46 & 0.69 \\
\hline & ID: NGP & -0.11 & -0.48 & -0.20 & -0.07 & ID: NGP & -0.60 & -0.99 & -0.13 & -0.44 \\
\hline & ID:MGP & 0.52 & 0.84 & -0.10 & 0.50 & ID:MGP & -0.01 & 0.36 & -0.25 & -0.33 \\
\hline & ID: ICP & 0.00 & -0.01 & 0.08 & -0.01 & ID: ICP & 0.44 & 0.06 & 0.03 & 0.08 \\
\hline \multirow{7}{*}{ MGP } & $r$ (PGXMGP) & $0.39 *$ & $0.46^{*}$ & $0.42^{\star}$ & 0.07 & $r$ (PIXMGP) & -0.29 & $-0.35^{\star}$ & $-0.44^{*}$ & $-0.68^{*}$ \\
\hline & $D: P G$ & 0.66 & 0.99 & 0.34 & 0.49 & $\mathrm{D}: \mathrm{PI}$ & -0.54 & -0.44 & -0.28 & -0.36 \\
\hline & ID: CP & -0.70 & -0.66 & -0.22 & -0.99 & ID: CP & -0.03 & 0.29 & 0.03 & 0.16 \\
\hline & ID:NEP & -0.08 & -0.07 & 0.02 & 0.59 & ID:NEP & -0.03 & 0.21 & 0.43 & 0.69 \\
\hline & ID: NGP & -0.11 & -0.45 & -0.03 & -0.02 & ID: NGP & -0.11 & -0.46 & -0.13 & -0.45 \\
\hline & ID: MP & 0.51 & 0.58 & 0.01 & -0.02 & ID: MP & 0.01 & 0.27 & -0.37 & -0.59 \\
\hline & ID: ICP & 0.11 & 0.07 & 0.30 & 0.02 & ID: ICP & 0.29 & -0.24 & -0.10 & -0.11 \\
\hline \multirow{9}{*}{ ICP } & r (PGXICP) & $0.34^{*}$ & $0.35^{*}$ & $0.36^{*}$ & 0.08 & r (PIXICP) & $-0.44^{*}$ & $-0.57^{\star}$ & -0.36 * & $-0.48 *$ \\
\hline & $\mathrm{D}: \mathrm{PG}$ & 0.18 & 0.15 & 0.28 & 0.09 & D:PI & 0.52 & -0.56 & -0.29 & -0.49 \\
\hline & ID: CP & -0.10 & -0.27 & -0.22 & -0.19 & ID: CP & -0.17 & 0.09 & 0.01 & 0.03 \\
\hline & ID:NEP & -0.09 & -0.01 & 0.06 & 0.03 & ID:NEP & -0.26 & -0.01 & 0.01 & 0.03 \\
\hline & ID: NGP & -0.02 & -0.09 & -0.03 & -0.01 & ID: NGP & -0.55 & -0.25 & -0.02 & -0.04 \\
\hline & ID: MP & 0.01 & -0.06 & 0.02 & 0.02 & ID: MP & 0.46 & -0.05 & 0.04 & 0.10 \\
\hline & ID: MGP & 0.36 & 0.63 & 0.25 & 0.14 & ID: MGP & -0.30 & 0.23 & -0.10 & -0.08 \\
\hline & k & $5.1 e^{-2}$ & $5.1 \mathrm{e}^{-2}$ & $5.1 e^{-2}$ & $3.9 \mathrm{e}^{-2}$ & Valor k & $4.1 \mathrm{e}^{-2}$ & $3.7 e^{-2}$ & $4.9 \mathrm{e}^{-2}$ & $4.3 e^{-2}$ \\
\hline & $\mathrm{R}^{2}$ & 0.78 & 0.70 & 0.66 & 0.47 & $\mathrm{R}^{2}$ & 0.36 & 0.51 & 0.26 & 0.61 \\
\hline
\end{tabular}

VAR -Variable; EF -Effect; PG - Grain productivity ( $\left.\mathrm{kg} \mathrm{ha}^{-1}\right)$; CP - Panicle length (cm); NEP -Number of panicle spikelet; NGP -Number of panicle grains; MP - Panicle mass (g); MGP - Panicle grain mass (g); ICP - Panicle harvest index; PI -Industrial productivity $\left(\mathrm{kg} \mathrm{ha}^{-1}\right)$; $\mathrm{r}$ - Coefficient of correlation; D -Direct contribution; ID - Indirect contribution; $\mathrm{R}^{2}$ - Coefficient of determination; $\mathrm{k}$ - Linearization coefficient; ${ }^{*}$ - Significant at $\mathrm{p} \leq 0.05$ by $\mathrm{F}$ test

observed between grain yield and the mass of panicle grains, with a positive direct effect of grain yield and a negative indirect effect of panicle length. In the same fertilization condition, there was a positive correlation between grain yield and panicle harvest index, mainly due to the negative indirect effect of panicle length and positive panicle grain mass.

Industrial productivity (Table 4) shows negative correlations with the number and mass of panicle grains, given by the negative direct effect of industrial productivity and positive indirect effect via the number of panicle spikelets. The correlation of industrial productivity with the panicle harvest index showed a negative relationship in all nitrogen doses, directly negatively influenced by industrial productivity. In these conditions, it was observed that the variables panicle grain mass and panicle harvest index favor the increase of grain yield, a fact also observed in the soybean/ oat system. On the other hand, the increase in the variables: panicle grain mass, panicle harvest index and number of panicle grains tend to reduce industrial productivity; thus, the need to define managements that can balance these variables is highlighted.

The productive potential of oats is due to its efficiency in the processes of absorption, remobilization and use of nitrogen, so that grain and industrial productivity are significantly increased with greater nitrogen availability (Kolchinski \& Schuch, 2003; Beche et al., 2014; Silva et al., 2016). De et al. (2007) obtained positive responses in productivity and oat inflorescence 
components by increasing $\mathrm{N}$-fertilizer application. Among the variables of the inflorescence, panicle mass is the most effective in showing alteration, either by cultivars or by management (Kurek et al., 2002; Marolli et al., 2017a). However, several studies have determined positive correlations of grain productivity with panicle grain mass (Alves \& Kist, 2010; Pecio \& Bichonski, 2010), which tends to increase with the increase in nitrogen, a result also found in this research (Tables 2, 3 and 4). Unlike other cereals, panicle grain weight in white oats corresponds to approximately 80 to $85 \%$ of the panicle mass (Chandhanamutta \& Frey, 1973). This explains the strong indirect relationship between panicle mass and panicle grain mass.

Wang et al. (2009), studying nitrogen and potassium doses in oats, found that different fertilizer doses can significantly increase panicle mass and panicle length, with direct effects on grain yield. However, a negative indirect effect of panicle grain mass was observed via panicle length, negatively affecting productivity (Tables 3 and 4), similar results were also found by Spasova et al. (2018). Research by Hawerroth et al. (2015) showed that the industrial productivity of oats is improved by the number of grains in the panicle with consequent reduction in the average grain mass. However, in this study, the increase in the number of grains in the panicle reduced industrial productivity, in line with the results observed by Benin et al. (2005).

\section{Conclusions}

1. The mass and number of panicle spikelets and the panicle grain mass, have a greater contribution in promoting alterations by increasing nitrogen in the soybean/oat system. Mass and number of spikelets of the panicle are the variables that make the greatest contribution to the corn/oat system.

2 . The increase in panicle grain mass and panicle harvest index increases grain productivity; however, together with the number of panicle grains, they reduce industrial productivity, regardless of the cultivation system.

\section{ACKNOWLedgements}

The authors would like to thank the Conselho Nacional de Desenvolvimento Científico e Tecnológico (CNPq), the Fundação de Amparo à Pesquisa do Estado do Rio Grande do Sul (FAPERGS), Coordenação de Aperfeiçoamento de Pessoal de Nível Superior (CAPES) and the Universidade Regional do Noroeste do Estado do Rio Grande do Sul (UNIJUÍ) for the resources allocated to the development of this research and the scholarships for Scientific and Technological Initiation and Research Productivity.

\section{Literature Cited}

Alves, A. C.; Kist, V. Composição da espigueta de aveia branca (Avena sativa L.). Revista Brasileira de Agrociência, v.16, p.2933, 2010.

Arenhardt, E. G.; Silva, J. A. G. da; Gewehr, E.; Oliveira, A. C. de; Binello, M. O.; Valdiero, A. C.; Gzergorczick, M. E.; Lima, A. R. C. de. The supply of nitrogen in wheat yield by year condition and succession system in Southern Brazil. African Journal of Agricultural Research, v.10, p.4322-4330, 2015.
Aseeva, T. A.; Melnichuk, I. B. Dependence of various oat ecotypes' yield capacity on climatic factors in the middle Amur region. Russian Agricultural Sciences, v.44, p.5-8, 2018. https://doi. org/10.3103/S1068367418010056

Beche, E.; Benin, G.; Bornhofen, E.; Dalló, S. C.; Sassi, L. H. S.; Oliveira, R. de. Eficiência de uso de nitrogênio em cultivares de trigo pioneiras e modernas. Pesquisa Agropecuária Brasileira, v.49, p.948-957, 2014. https://doi.org/10.1590/ S0100-204X2014001200005

Benin, G.; Carvalho, F. I. F.; Oliveira, A. C.; Hatwig, I.; Schmidt, D.; Vieira, E. A.; Valério, I. P.; Silva, J. A. G. Estimativas de correlações genotípicas e de ambiente em gerações como elevada frequência de heterozigotos. Ciência Rural, v.35, p.523529, 2005. https://doi.org/10.1590/S0103-84782005000300006

Chandhanamutta, P.; Frey, K. J. Indirect mass selection for grain yield in oat populations. Crop Science, v.13, p.470-473, 1973. https://doi.org/10.2135/cropsci1973.0011183X001300040023x

Coelho, A. P.; Rosalen, D. L.; Faria, R. T. Vegetation indices in the prediction of biomass and grain yield of white oat under irrigation levels. Pesquisa Agropecuária Tropical, v.48, p.109117, 2018. https://doi.org/10.1590/1983-40632018v4851523

Cover, C.; Federizzi, L. C.; Pacheco, M. T. Caracterização fenotípica e genotípica de caracteres agronômicos em uma população de linhagens recombinantes de aveia (Avena sativa L.). Ciência Rural, v.41, p.573-579, 2011. https://doi.org/10.1590/S010384782011005000030

De, K.; Zhou, Q.; Liu, W.; Xu, C.; Wang, D. Effects of nitrogen application on the yield and quality of oat in Qinghai-Tibet plateau. Qinghai Academy of Animal and Veterinary Science, v.29, p.43-48, 2007.

Hawerroth, M. C.; Silva, J. A. G. da; Woyabb, L. G.; Zimmer, C. M.; Groli, E. L.; Oliveira, A. C. de; Carvalho, F. I. F. de. Correlations among industrial traits in oat cultivars grown in different locations of Brazil. Australian Journal of Crop Science, v.9, p.1182-1189, 2015.

Klink, K.; Wiersma, J. J.; Crawford, C. J.; Stuthman, D. D. Impacts of temperature and precipitation variability in the Northern Plains of the United States and Canada on the productivity of spring. International Journal of Climatology, v.34, p.28052818, 2014. https://doi.org/10.1002/joc.3877

Kolchinski, E. M.; Schuch, L. O. B. Eficiência no uso do nitrogênio por cultivares de aveia branca de acordo com a adubação nitrogenada. Revista Brasileira de Ciência do Solo, v.27, p.1033-1038, 2003. https://doi.org/10.1590/S010006832003000600007

Kuinchtner, A.; Buriol, G. A. Clima do estado do rio grande do sul segundo a classificação climática de Köppen e Thornthwaite. Disciplinarum Scientia, v.2, p.171-182, 2001.

Kurek, A. J.; Carvalho, F. I. F. de; Cruz, P. J.; Lorencetti, C.; Cargnin, A.; Simioni, D. Variabilidade em genótipos fixos de aveia branca estimada através de caracteres morfológicos. Revista Brasileira de Agrociência, v.8, p.13-17, 2002.

Marolli, A.; Silva, J. A. G. da; Mantai, R. D.; Brezolin, A. P.; Gzergorczick, M. E.; Lambrecht, D. M. Oat yield through panicle components and growth regulator. Revista Brasileira de Engenharia Agrícola e Ambiental, v.21, p.261-266, 2017a. https://doi.org/10.1590/1807-1929/agriambi.v21n4p261-266 
Marolli, A.; Silva, J. A. G. da; Romitti, M. V.; Mantai, R. D.; Scremin, O. B.; Frantz, R. Z.; Sawicki, S.; Arenhardt, E. G.; Gzergorczick, M. E.; Lima, A. R. C. Contributive effect of growth regulator Trinexapac-Ethyl to oats yield in Brazil. African Journal of Agricultural Research, v.12, p.795-804, 2017b. https://doi. org/10.5897/AJAR2016.11784

Pecio, A.; Bichoński, A. Nitrogen fertilization and fungicide application as elements of oat production. Polish Journal of Environmental Studies, v.19, p.1297-1305, 2010.

Prando, A. M.; Zucareli, C.; Fronza, V.; Oliveira, F. A. de; Oliveira Júnior, A. Características produtivas do trigo em função de fontes e doses de nitrogênio. Pesquisa Agropecuária Tropical, v.43, p.34-41, 2013. https://doi.org/10.1590/S198340632013000100009

Santos, H.G. dos; Jacomine, P.K.T.; Anjos, L.H.C. dos; Oliveira, V.A. de; Oliveira, J.B. de; Coelho, M.R.; Lumbreras, J.F.; Cunha, T.J.F. (Ed.). Sistema brasileiro de classificação de solos. $2^{\text {a }}$ ed. Rio de Janeiro: Embrapa Solos, 2006. 306p.

Scremin, O. B.; Silva,J. A. G. da; Mamann, A. T. W. de, Mantai, R. D.; Brezolin, A. P.; Marolli, A. Nitrogen efficiency in oat yield through the biopolymer hydrogel. Revista Brasileira de Engenharia Agrícola e Ambiental, v.21, p.379-385, 2017. https:// doi.org/10.1590/1807-1929/agriambi.v21n6p379-385

Silva, J. A. G. da; Goi Neto, C. J.; Fernandes, S. B. V.; Mantai, R. D.; Scremin, O. B.; Pretto, R. Nitrogen efficiency in oats on grain yield with stability. Revista Brasileira de Engenharia Agrícola e Ambiental, v.20, p.1095-1100, 2016. https://doi. org/10.1590/1807-1929/agriambi.v20n12p1095-1100
Silva, J. A. G. da; Mamann, A. T. W.; Scremin, O. B.; Carvalho, I. R.; Pereira, L. M.; Lima, A. R. C. de; Lautenchleger, F.; Basso, N. C. F.; Argenta, C. V.; Berlezi, J. D.; Porazzi, F. U.; Matter, E. M.; Norbert, L. Biostimulants in the indicators of yield and industrial and chemical quality of oat grains. Journal of Agricultural Studies, v.8, p.68-87, 2020. https://doi.org/10.5296/jas.v8i2.15728

Singh, D. The relative importance of characters affeting genetic divergence. The Indian Journal of Geneticsand Plant Breeding, v.41, p.237-245, 1981.

Song, X.; Zhou, G.; Ma, B.; Wu, W.; Ahmad, I.; Zhu, G.; Yan, W.; Jiao, X. Nitrogen application improved photosynthetic productividy, clorophyll fluorescence, yield and yield components of two oat genotypes under saline conditions. Agronomy, v.9, p.1-17, 2019. https://doi.org/10.3390/agronomy9030115

Souza, C. A.; Figueiredo, B. P.; Coelho, C. M. M.; Casa, R. C.; Sangoi, L. Arquitetura de plantas e produtividade da soja decorrente do uso de redutores de crescimento. Bioscience Journal, v.29, p.634-643, 2013.

Spasova, D.; Valcheva, D.; Atanasova, B.; Burovska, A.; Spasov, D.; Ilievski, M. Comparative analysis of oats quality grown in conditions of organic production. Agricultural Sciences, v.71, p.437-444, 2018. https://doi.org/10.7546/CRABS.2018.03.18

Tedesco, M. J.; Gianello. C.; Bissani, C. A.; Bohnen, H.; Volkweiss, S. J. Análise de solo, plantas e outros materiais. 2.ed. Porto Alegre: UFRGS, 1995. 147p.

Wang, J.; Yan, H.; Zhou, Q. Effects of different levels of nitrogen and potassium on production trait of Qingyin No.1 oat. Qinghai Academy of Animal and Veterinary Sciences, v.5, p. 81-85, 2009. 